\title{
19. Yüzyılın İkinci Yarısında Osmanlı Devleti'nde Otel ve Misafirhanelere Dair Düzenlemeler
}

Regulations about Guest Houses and Hotels in the Second Period of 19th Century of Ottoman Empire

\author{
Emrah ÇETIN* \\ *Yrd. Doç. Dr., Bartın Üniversitesi, Edebiyat Fakültesi Tarih Bölümü, 74100, Kutlubey Kampüsü, Bartın. \\ E-posta:emrahc@bartin.edu.tr \\ ORCID: 0000-0002-9330-6468
}

MAKALE BILGILERI

Makale ișlem bilgileri:

Gönderilme tarihi: 29 Eylül 2017

Düzeltme: 21 Aralık 2017

Kabul: 6 Şubat 2018

Anahtar sözcükler: Osmanl

Devleti, Otel, Misafirhane, Turizm,

Konaklama.

ARTICLE INFO

Article history:

Submitted: 29 September 2017

Resubmitted: 21 December 2017

Accepted: 6 February 2018

Key words: Ottoman Empire, Hotel, Guest Houses, Tourism, Accomodation. öz

XIX. yüzyılda dünyada turizmin gelișimine paralel olarak ticari, dinî, tarihî ve kültürel amaçlarla her geçen sene daha fazla sayıda insan Osmanlı topraklarına gelmeye başlamıştır. Bununla birlikte başta i̇stanbul olmak üzere liman kenti özelliğine sahip birçok Osmanlı şehrinde çok sayıda otel ve misafirhane açılmaya başlamıştır. Bunların sayısındaki hızlı artış hükümeti bu alanda yasal bir düzenleme yapmaya zorlamıștır. Gerek otel ve misafirhanelerin kuruluşu ve işletmesi gerekse konaklayacak turistlerin kayıt altına alınması intiyacını karşılamak adına bazı düzenlemeler yapılmıştır. Bu kapsamda dokuz maddelik bir talimatname hazırlanarak otel ve misafirhanelerle ilgili yasal zemin olușturulmaya çalıșılmıștır. Bu araștırmada; Osmanlı Devleti'nin son döneminde otel ve misafirhanelerle ilgili olarak yapılan düzenlemeler ele alınacaktır. Bu doğrultuda hükümeti konaklama yerleri ile ilgili düzenleme yapmaya zorunlu kılan nedenler, yapılan yasal düzenlemeler, bunların uygulanması ve ortaya çıkan sorunlar ele alınacaktır. Böylelikle Türk turizminin tarihsel gelişimi noktasında birtakım çıkarımlarda bulunma olanağı sağlanacaktır.

\section{ABSTRACT}

In 19th century, parallely with the development of tourism, more and more people started to visit Ottoman lands with cultural, religious, historical and commercial reasons. In the meantime, a lot of guest houses and hotels began to be opened in the most of coastal towns of Ottomans, particularly in istanbul. Therefore, the government needed to make legal regulations in this field. Some regulations were made about both the establishment and management of the guest houses \& hotels and the recordings of the tourists staying there. In this context, a regulation consisting nine points was prepared in order to provide a legal basis about guest houses and hotels. In this study, it is tried to go over the regulations made about guest houses and hotels in the last period of Ottoman Empire. Besides, the reasons why the government needed to make regulations about accomodation facilities, the regulations made, implementation of these regulations and encontered problems are discussed. Thus, it will be possible to make inferences about the development of Turkish tourism.

\section{Gíriş}

Osmanlı Devleti, XVIII ve XIX. yüzyıllarda iktisadi, idari, askerî vb. alanlarda olduğu gibi turizm meselesinde de Avrupa'yı geriden takip etmiş, yaşanan gelişmelere ve ortaya çıkan şartlara ayak uydurmaya çalışmıştır. XIX. yüzyılda Avrupa'nın Londra, Paris, Viyana gibi şehirlerinde düzenlenen sergi ve fuarlar binlerce insanın başka ülkelere seyahat etmesine vesile olduğundan bu dönemde turizmin gelişiminde büyük rol oynamıştır (Olalı ve Timur 1988). Avrupa devletlerinin artan üretimlerine pazar ve hammadde kaynakları bulmak amacıyla düzenledikleri bu sergilerin ilk örneği, Avrupa'nın en güçlü sanayi ülkelerinden olan İngiltere' nin girişimleriyle 1851 yılında Londra'da açılan Dünya Fuarı'dır. Sergiye Amerika Birleşik Devletleri, Fransa, Felemenk ülkeleri, İspanya, Portekiz, Prusya, Rusya, Hindistan gibi ülkelerden binlerce insan katılmıştır. Osmanlı Devleti de bu konuda yaşanan gelişmeleri yakından takip etmiş ve sergiye iştirak etmiştir. Bu hususta, Ceride-i Havadis Gazetesi'nin 24 Zilkade 1266 (1 Ekim 1850) tarihli nüshasında neşredilen bir hükümet bildirisinde; imparatorluğun sergiye katılmasındaki 
amacı ülke topraklarının verimliliğini göstermek, Osmanlı tebaasının tarım, sanayi ve sanat alanlarındaki kabiliyetini kanıtlamak ve hükümetin ülkenin gelişmesi yolunda sarf ettiği gayreti ortaya koymak olarak gösterilmektedir (Önsoy 1983). Zira Tanzimat sonrası çağdaşlaşma sürecine giren Osmanlı Devleti'nin bu dönemde başlayan söz konusu uluslararası etkinliklerden uzak kalması, Avrupa'nın dört bir köşesinde düzenlenen sergi ve fuarlarla ilgilenmemesi düşünülemezdi. Nitekim Osmanlı Devleti, bu fuarlardan birçoğuna katılmış ve bu organizasyonların başladığ 1851 yılından sadece 12 yıl sonra, kendisi de İstanbul'da uluslararası bir fuar organize etmiştir (Kanca 2013). 27 Şubat 1863'te İstanbul Atmeydanı'nda açılan Sergi-i Umumi-i Osmani'ye, İngiltere, Fransa ve Avusturya'dan birçok kişi katılmıştır. Sergi, Avrupa'da büyük ilgi uyandırmış, başta Viyana olmak üzere çeşitli Avrupa şehirlerinden aralarında gazeteci, iş adamı ve fabrikatörlerin de bulunduğu gruplar sergiyi gezmek üzere İstanbul'a gelmiştir. Bunlar aynı zamanda Osmanlı topraklarını toplu halde ziyaret eden ilk turist kafileleridir. 1863 Nisan ay1 başlarında gelen 142 kişilik bir grubu 450 kişilik başka bir grup takip etmiştir. Sonuncu kafile İstanbul'da beş gün kaldıktan sonra İzmir'e geçerek oradan ülkelerine dönmüşlerdir. Viyana'dan gelen başka bir grup ise iki gün sergiyi gezdikten sonra İstanbul'un tarihi yerlerini ve Boğazları gezmek maksadıyla bir müddet daha burada kalmışlardır. Ayrıca çeşitli Fransız ve İngiliz kafileleri de gruplar halinde İstanbul'a seyahatler düzenlemişlerdir (Önsoy 1983).

XIX. yüzyılda Osmanlı Devleti, dünya turizm destinasyonları içinde en çok konuşulan konulardan biridir. Zira oldukça çeşitli bir etnik yapıya sahip olan devlet içinde söz konusu milletlerin her birisi çeşitli amaçlarla iç seyahatler gerçekleştiriyordu. Bunun yanı sira Osmanlı toprakları ticari ve dinî açıdan da büyük turizm potansiyeline sahipti. Osmanlı Devleti, Mekke, Medine, Kudüs gibi üç büyük dine inananlar için kutsal kabul edilen şehirleri elinde bulunduruyor olması nedeniyle tüm dünyadan ziyaretçi çekiyordu. $\mathrm{Bu}$ dönemde Osmanlı turizminin gelişimini sağlayan gelişmelerden biri de misyonerlik faaliyetleridir. Osmanlı topraklarının dört bir tarafında çalışan misyonerlerin yazdıkları raporlar, kitaplar ve gazete yazılarının Batı'da yaygınlaşmaya başlamasının ardından Osmanlı vatanına karşı duyulan ilgi daha da artmıştır. Bu da Osmanlı ülkesini ziyaret eden turist sayısının zamanla artmasina neden olmuştur (Nance 2007).

Osmanlı toprakları XIX. yüzyılın ikinci yarısindan itibaren giderek daha fazla sayıda turist çekmeye başlamıştır. Artan taleple birlikte yeni konaklama tesisleri, lokantalar, eğlence yerleri gibi liman kentlerinde giderek artan sayıdaki turistlerin ulaşım, konaklama, yiyecek, eğlence vb. gereksinimlerini karşılamak üzere yeni tesisler oluşturulmaya başlanmıştır (Özdemir 2011). Bu maksatla bazı girişimciler hükümete başvurarak yapacakları yatırım için izin alma yarışına girişmişlerdir. Bunlardan birisi olan İngiliz Cems Misiri, 1864 senesinde hükümete başvurarak, Beyoğlu'nda ve İstanbul'daki çeşitli tarihi bölgelerde yapılacak oteller için "Osmanlı Otelleri Kumpanyası" adıyla bir şirket kurulması hususunda ruhsat verilmesi talebinde bulunmuş (BOA. İ.MVL. , 529/23721, 10 Şevval 1280/19 Mart 1864) ve gerekli izinleri almıştır (BOA. İ.MVL. , 529/23721, 10 Zilkade 1281/6 Nisan 1865). Özellikle 1883 yılında "Orient Express" in ilk seferine başlayarak, yarım düzine ülkeden geçip Avrupa ile İstanbul'u bağlamasıyla birlikte Osmanlı topraklarının turizm potansiyeli daha da artmıştır (Özdemir 2011). XIX. yüzyılda Osmanlı topraklarına Avrupa sermayesinin girdiği ilk bölge Batı Anadolu'dur. İngiliz sermayesi ile inşa edilen İzmir-Aydın demiryolu bir taraftan Osmanlı topraklarını Batı kapitalizmine açarken öte yandan da bölgenin iktisadi açıdan kalkınması noktasında önemli katkılar sağlamıştır (Kurmuş 2012). İngiliz sermayesi ile inşa edilen demiryolu İzmir limanının ticari değerini daha da artırmış ve şehrin gelişimini hızlandırmıştır. Şüphesiz ulaşım olanaklarının gelişiminin turizme olumlu yönde katkısı vardır. Bu durum demiryolunun yap1mından sonra başta İzmir olmak üzere Batı Anadolu kentlerinin turizm potansiyellerinin artmış olmasında da görülmektedir. Zira yüzyılın ikinci yarısından itibaren İzmir'de bulunan konaklama tesislerinin sayısında hızlı bir artış olmuştur. Benzer bir gelişimin Varna kentinde de yaşand1ğ1 görülmektedir. Rusçuk-Varna demiryolunun 
inşasının ardından bölgede önemli oranda ticaret ve nüfus artışı olduğu görülmektedir. Bu iktisadi canlanmanın da etkisiyle Tuna Valisi Mithat Paşa'nın çabalarıyla Varna'da otel inşası için hisse senetlerinden teşekkül eden bir şirket kurulmuştur. Şirketin hisse sayısı 400 ve sermayesi de 4.000 liradır (Akyıldız 2005). Bu iki örnekte de görüldüğü üzere başta demiryollarının inşa edilmesi olmak üzere Osmanlı topraklarında ulaşım olanaklarının gelişimi ve Avrupa sermayesinin Osmanlı topraklarına yönelişi ülkede turizmin gelişimine katkı sağlamıştır.

Taşımacılıkta meydana gelen gelişmeler yabanc1 şirketlerin Osmanlı topraklarında yatırım yapmasına neden olmuştur. Bu gelişmelere paralel olarak konaklama sektöründe uluslararası standartlara sahip tesisler hizmet vermeye başlamıştır. 1841 yılında Osmanlı İstanbulu'nun ilk oteli olma sıfatını taşıyan Otel d'Angleteer, 1892'de açılan Büyük Londra Oteli ve 1895 senesinde kurulan Pera Palas, bu dönemde Avrupa standartlarına sahip otellerin başında geliyordu. Bunların yanında Petersburg, Lüxemburg, Paris, Univers, Grande Bretange, Bizans, Orient, Elysee Françis, Grand Balcon, Peşte ve Tobias otelleri de bu dönemin otelleri arasında yer alıyordu (Yılmaz 2007). Bununla birlikte özellikle İstanbul'un turizm potansiyelinin artmasına bağlı olarak Osmanlı topraklarını Avrupa'ya tanıtmak için birtakım girişimler olmuştur. Örneğin; her başkentte yaptıkları seyahati kısaca anlattıkları "Enrot" isimli bir gazete çıkartan ve gezi için 1895 yılında İstanbul'da bulunan Fransız gazeteciler Papliyo ve Lerova, İstanbul'u tanıtacak bir gazete çıkarmak için hükümetten izin istemişlerdir. Yapılan incelemelerin ardından gazetenin basımından önce kontrol edilmesi şartıyla kendilerine onay verilmiştir (BOA. DH.MKT., 386/73, 26 Zilhicce 1312/20 Haziran 1895). Ayrica 1898 senesinde İstanbul'un tarihi ve turistik yerleriyle coğrafya ve topografyasindan bahseden "İstanbul Rehberi" isimli kitabın basımına çalışılmıştır (BOA. MF.MKT., 388/52, 24 Şevval 1315/18 Mart 1898).

Osmanlı Devleti'nde turizmin gelişimine paralel olarak otel ve konaklama yerlerinin sayısı hızla artmaya başlamıştır. Bununla birlikte turistik merkezlere yakın noktalarda ikamet eden çok sa-

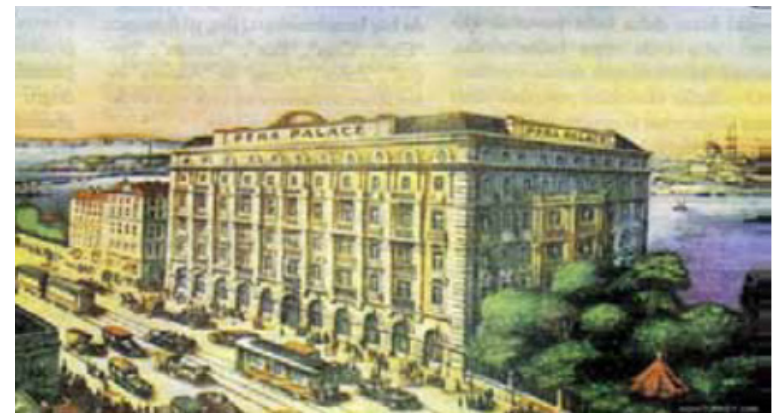

Fotoğraf 1. 19. Yüzyıl Sonlarında İstanbul'un Ünlü Otellerinde Pera Palas (Yakartepe ve Binan 2011).

yıda gayrimüslim Osmanlı vatandaşının evinin bir veya birkaç odasını kiraya vermek suretiyle konaklama hizmeti sunduğu görülmektedir. Bunun üzerine otel ve konaklama yerlerine dair birtakım yasal düzenlemelerin yapılması zorunluluk haline gelmiştir.

Gerek bunların kuruluşu ve işletmesi gerekse konaklayacak turistlerin kayıt altına alınması ihtiyacını karşılamak adına bazı düzenlemeler yapılmıştır. Bu doğrultuda 1887 yılında, İstanbul ve çevresindeki konaklama faaliyetlerini kontrol altında tutmak ve bunlara düzen vermek maksadıyla "Dersaâdet ve Bilâd-ı Selâse'de Bulunan Otel ve Misafirhâneler Hakkında Talimattır" başlıklı 11 maddelik bir düzenleme ortaya konulmuştur (BOA. ŞD. 2568/9, 8 Receb 304/2 Nisan 1887). Söz konusu talimatı hazırlayan kişi polis müşaviri Mösyö Bunt'tur. Bunt'un hazırlayarak hükümete sunduğu tasarı niteliğindeki talimat, bu alanda yapılacak olan yasal düzenlemelerin temelini oluşturmaktadır (BOA. İ.DH., 1008/79628, 11 Safer 304/9 Kasım 1886). Bununla birlikte Şûra-yı Devlet dairesinde yapılan birçok değerlendirmede otel ve konaklama yerlerinin kuruluşu, işletmesi ve turistlerin ikameti noktalarında çok sayıda öneri dile getirilmiş ve bu doğrultuda düzenlemeler yapılmıştır. Yapılan incelemeler neticesinde 1895 yılında, önceki düzenlemeler esas alınmak üzere aynı adla dokuz maddeden oluşan yeni bir talimat çıkarılmıştır (Düstûr 1335: 187-188; Düstûr 1939: 1565-1566; BOA. HR. İD., 178/43, 14 Ramazan 312/11 Mart 1895; BOA. HR.HMŞ.İ̧O. , 60/26, 14 Ramazan 312/11 Mart 1895). Bu araștırmada, Osmanlı arşiv belgeleri ve tarihsel veriler ışığında Osmanlı 
Devleti'nin son döneminde otel ve misafirhanelere dair düzenlemeler ile Osmanlı hükümetinin meseleye bakış açısı değerlendirilmiştir. Böylece Osmanlı turizm tarihi araştırmalarına katkı sağlanması amaçlanmıştır. Bununla birlikte XIX. yüzyılın ikinci yarısından itibaren hızla büyüyen sermayesi ile devletler için önemli bir gelir kaynağ 1 haline gelen turizm alanında Osmanlı Devleti'nin edindiği yer, uluslararası sermayenin Türk topraklarına yönelişi ve Osmanlı turizminin uluslararası sermaye içindeki payının ortaya konulması noktasında fikir yürütülmesine katk1da bulunulmuştur.

\section{ALANYAZIN TARAMASI}

Osmanlı turizm tarihi üzerine yapılan araştırmalar oldukça sınırlıdır. Turizm alanında yapılan birçok araştırmada Türk turizminin tarihsel boyutu üzerine çok kısa ve genellikle birbirinin tekrarı niteliğinde değerlendirmeler yapılmaktadır. Araştırmacılar, "Türkiye'de Turizmin Tarihsel Gelişimi" (Yılmaz 2007), "Kervansaraylar", "Osmanlılar'da Hac" (Kozak, Kozak ve Kozak 2000) gibi başlıklar altında genel hatlarıyla Türk turizmine dair bilgiler vermektedir. Bunun yanı sıra Osmanlı turizminin gelişiminde önemli bir yeri bulunan 1863 Sergi-i Umumi-i Osmani'ye dair de araştırmalar bulunmaktadır. Bunlar, "Osmanlı İmparatorluğu'nun Katıldığ rası Sergiler ve Sergi-i Umumi-i Osmani (1863 İstanbul Sergisi)” (Önsoy 1983), “Türkiye'de Turizmin Başlaması: Osmanlı'da Sanayileşme Çabaları: Sergi-i Umumi-i Osmanî (1863 İstanbul Uluslararası Sergisi)" (Özdemir 2011) ve "XIX. Yüzyılın İkinci Yarısında Uluslararası Osmanlı Fuarı: 1863-Sergi-i Umumi-i Osmanî" (Kanca 2013) adlı çalışmalardır. Bunlarla birlikte Türk turizminin tarihsel gelişimini ortaya koymak noktasında katkı sağlayacak daha spesifik ve kapsamlı araştırmalar yapılmaya başlanmıştır. Bunlar arasında; "Seyyah'tan 'Turist'e, 'Sınâat'tan 'Endüstri'ye: "Ecânib Sınâatı," (Türkiye'e 'Ecânib Sınâatı' ya da “Turizm Endüstrisi')” (Toprak 1993), "Zamansız Bir Teşebbüs: I. Dünya Savaşı Yıllarında Osmanlı İmparatorluğu'nda Turizmi Geliştirme Gayretleri" (Yüksel 2010) ve "II. Abdülhamid Döneminde Bilimsel, Kültürel ve Turistik Amaçlarla Osmanlı
Ülkesine Gelen Almanlar" (Yüksel 2012) başlıklı çalışmaları sıralamak mümkündür. Bunların yanı sıra tarafımızdan hazırlanan "Osmanlı Turizm Tarihinden Kesitler: Ernest Arman'ın Seyahat Acentesi Kurma Girişimleri"' (Çetin 2017) başlıklı makale de Türk turizm tarihinin incelenmesine katkı sağlamayı amaçlamaktadır.

\section{YÖNTEM}

Güvenilir sonuca ulaşmayı amaçlayan her araştırma bilim ve mantığa uygun şekilde bir yöntem kullanır. Sosyal bilimler ve doğa bilimlerinin yöntemleri birbirinden farklıdır. Tarihin ana temasını oluşturan tarihî olayları doğa bilimlerinin yöntemlerinden olan sıkı bir tümdengelim ya da tümevarım ile değerlendirmek oldukça zordur. Çünkü bu bilimlerin ilgilendiği konuların doğruluğu deney ile ortaya konurken tarihte böyle bir olasılık yoktur. Ayrıca doğa bilimlerinde elde edilen araştırma sonuçları yüzyıllar boyunca özelliğini koruyabilirken -yerçekimi, suyun kaldırma kuvveti, kaynama noktası vb.-, sosyal bilimlerde her kültürün ya da kuşağın kendine özgü farklı özelliklere sahip olduğu düşünüldügü̈nde sonuçların da değişkenlik gösterebileceği muhakkaktır (Sander 1973; Kozak 2017). Tarihi bilim haline getiren araştırıcılığı ve sorgulayıc1lığıdır. Geçmişten bugüne tarih yazınına katkıda bulunan araştırmacılar başlıca dört ana yazış tarzını benimsemişlerdir. Bunlar; rivayetçi tarih, öğretici tarih, neden nasılcı tarih ve içtimai tarih yazış yöntemleridir (Togan 1985). Tarihin yöntemi, tarihî olayları analiz etmek ve elde edilen bulgulara göre açıklamaktır. Tarihte bilgi esas olup, bilgiye ulaşmak başlıca gerekliliktir. Bilginin esasını ise tarihî kaynaklar oluşturur (Baykara 2010). Tarih kaynakları oldukça çeşitlilik gösterir. Başlıca kaynaklar; sözlü kaynaklar -tarihî şiirler, hikâyeler, efsaneler, destanlar vb.-, yazılı, çizili, sesli ve görüntülü kaynaklar -arşiv malzemeleri, resim ve fotoğraflar, gazete ve dergiler, biyografiler, hatıralar, seyahatnameler vb.-, müzelik malzeme-mezar taşları, madalyalar, paralar, arma ve mühürler vb.- olarak sınıflandırılabilir (Kütükoğlu 2014). Tarihçi, hikâyesini kurgulamak için kayıtlardan, belgelerden, maddi buluntulardan ve bazen de toplumsal belleğin

\section{4 - Anatolia: Turizm Araştırmaları Dergisi}


ürünlerinden, yani efsanelerden, türkülerden ve masallardan yararlanır. Bunun için kapsamlı bir kaynak taraması yapması gerekir. Araştırmanın hazırlık aşamasında konuyla ilgili bilgilerin nerelerde bulunabileceğinin, bunlara nasıl ulaşılabileceğinin tespit edilmesi, fikrî ve teknik hazırlık bakımından önem taşımaktadır. Araştırmacının öncelikle araştırma yöntemini belirlemesi ve buna uygun olarak değerlendirme sürecine girmesi gereklidir (Cebeci 2002).

$\mathrm{Bu}$ araştırma, tarama modeli kullanılarak hazırlanmıştır. Tarama, geçmişte ya da halen var olan bir durumu gerçekliğe en uygun şekilde tespit etmeyi amaçlayan araştırma modelidir. Araştırmaya konu olan olay, birey ya da nesne, kendi koşulları içinde ve olduğu gibi tanımlanmaya çalışılır. Önemli olan, var olanı değiştirmeye kalkışmadan gözlemleyebilmektir. Araştırmacı, önceden tutulmuş çeşitli kayıtlara -yazılı belge ve istatistikler, resimler, ses ve görüntü kayıtları vb.-, eski verilere ve alandaki kaynak kişilere başvurarak, elde edeceği dağınık verileri, kendi gözlemleri ile bir sistem içinde bütünleştirerek yorumlayabilir. Tarama modeli ile yapilan bir araştırmanın iki temel sınırlılığı vardır. Bunlar, veri bulma ve kontrol güçlüğüdür. Özellikle tarih araştırmalarında geçmişe ait yeterli verilerin bulunması ya da elde edilen bulguların güvenilirliğinin analiz edilmesi önemli problemlerdir (Karasar 2016).

Uygulanan tarama modelinde öncelikle konuyla ilgili veri analizi yapılmıştır. Bu noktada tarihsel gerçekliğe uygun olacak en güvenilir kaynaklara ulaşılmaya çalışılmıştır. Tarih araştırmalarında birinci el ve en güvenilir kaynak malzemesi arşiv belgeleridir. Bu doğrultuda öncelikle Osmanlı Arşivi'nde tarama yapılmış, konuyla ilgili belgeler tespit edilmiş, ardından bunların günümüz Türkçesine aktarımı yapılarak analiz sürecine geçilmiştir. Elde edilen belgeler zaman ve mekân esasları göz önünde bulundurularak sınıflandırılmıştır. Bu noktada Osman11 Devleti'nin son döneminde -19. yüzyılın ikinci yarısından 20. yüzyıl başlarına kadar- otel ve misafirhanelere dair yapılan düzenlemeler esas alınarak araştırma sınırlılı̆̆ ca bazı gazeteler ve resmî yayınlar taranarak ya- pılan düzenlemelerin toplumsal yansımaları incelenmeye çalışılmış ve arşiv belgelerinden elde edilen bilgilerin güvenilirliği başka kaynaklarla desteklenmiştir. Araştırmada, ele alınan dönemde Osmanlı Devleti'nde konaklama tesislerinin gelişimi, otel ve misafirhanelere dair ne gibi düzenlemeler yapıldığı, söz konusu düzenlemelerin ortaya çıkış sebepleri, yapılan yasal düzenlemelerin uygulanması, uygulanmadan doğan problemlerin neler olduğu gibi sorulara cevap aranmaya çalışılmıştır. Bu kapsamda yapılan analiz neticesinde Osmanlı hükümetini bu alanda düzenleme yapmaya iten etmenlerin neler olduğu, yapılan yasal düzenlemelerin kapsamı, uygulanması ve ortaya çıkan sonuçlar ayrıntılı bir şekilde değerlendirilmiştir.

Bu araştırmanın amacı, Osmanlı Devleti'nin son döneminde otel ve misafirhanelere dair düzenlemeleri ortaya koymak ve hükümetin meseleye bakış açısını değerlendirmektir. Böylece Osmanlı turizm tarihi araştırmalarına katkı sağlanması amaçlanmıştır. Bununla birlikte turizm alanında Osmanlı Devleti'nin edindiği yer, uluslararası sermayenin Türk topraklarına yönelişi ve Osmanlı turizminin uluslararası sermaye içindeki payının ortaya konulması noktasında fikir yürütülmesine katkıda bulunulacaktır. Araştırma yöntemi olarak öncelikle Osmanlı arşiv belgelerine dayanarak turizm alanında devletin göstermiş olduğu etkinliğe dair bilgiler derlenmiştir. Bu kapsamda yapılan yasal düzenlemeler ele alınmış, bunların turizme etki ve katkısı değerlendirilmiştir. Bu alanda yapılan düzenlemelerin kurumsal ve toplumsal karşılıkları değerlendirilerek uygulanabilirlikleri üzerinde durulmuş, uygulama alanında yaşanan sorunlar ortaya konulmuştur. Böylelikle birincil el kaynak niteliği taşıyan arşiv vesikalarına dayanarak Osmanlı turizminin gelişimine ve bu alanda gösterilen etkinliğe dair bilgiler araştırmacıların ilgisine sunulmuştur.

\section{Otel ve Misafirhanelerle ilgili Düzenleme Yapılmasını Zorunlu Kılan Nedenler}

Fransız İhtilali'nin getirdiği yeni sosyal ve hukuksal anlayış çerçevesinde kişisel hak ve hürriyetlerin korunması ve buna bağlı olarak öz- 
gürlük düşüncesinin bireyler üzerindeki etkisiyle birlikte seyahat özgürlüğü kavramı gelişti. Avrupa'da kendi ülkesinden başka yerlere seyahat eden insan sayısının artması nedeniyle birçok devlet seyahat edenler için pasaport bulundurma mecburiyeti getirdi (Eralp 1983). Batı'daki örneklerine benzer şekilde Osmanlı Devleti de artan iç ve diş seyahatleri düzenlemek için birtakım girişimlerde bulundu. Tanzimat'ın ilanından önce yapılan düzenlemelerle ülke içinde seyahat edeceklerin "Mürûr Tezkeresi" adı verilen bir izin belgesi alması zorunlu hale getirildi (Turna 2014). 10 Şubat 1841 tarihinde çıkarılan "Men-i Mürûr Nizâmnâmesi" adlı yönetmelikle iç seyahatin düzenlenmesi noktasında uygulanmakta olan kurallar yasal bir zemine oturtuldu (Çadırcı 1993). Ayrica bu dönemde yabanciların Osmanlı sınırları içinde pasaport taşımalarını öngören bir düzenleme yapıldı. 14 Şubat 1867 tarihinde "Pasaport Odası Nizâmnâmesi" adı altında çıkarılan yönetmelikle diş seyahatin düzenlenmesine çalışıldı. Buna göre; Osmanlı sınırlarına girecek ya da dışına çıacak herkesin bir pasaport bulundurması zorunlu hale getirildi (Çadırcı 1993). Osmanlı Devleti'nde iç ve dış seyahatleri düzenlemek için yapılan tüm bu çalışmaların temelinde iç güvenliğin sağlanması düşüncesi yatıyordu. Söz konusu düzenlemelerle gerek ülke içinde gerçekleştirilen gerekse yurtdışından Osmanlı topraklarına yönelen seyahatler kontrol altına alınmaya çalışılıyordu. Zira bu dönemde iç politikada ortaya çıkacak problemlerin uluslararası bir sorun haline dönüşme olasılığ $\breve{b}_{\text {bulunuyor- }}$ du. Bu sebeple hükümetin öncelikleri arasında iç güvenliğin sağlanması meselesi de yer alıyordu. Özellikle 1878 Berlin Antlaşması'yla başlayan dönemde iç ve diş politikada yeni bir dönemece girilmişti. Berlin Antlaşması'nın 23. maddesi Makedonya'da Avrupa devletlerinin denetiminde reformlar yapılmasını öngörürken, 63. maddesi Doğu Anadolu vilayetlerinde idari reformlar yapılmasını öngörmekteydi. Böylelikle yeni dönemde Osmanlı siyasetinin merkezine Doğu Anadolu'da "Ermeni Meselesi", Balkanlar'da ise "Makedonya Meselesi" oturacaktı (Özbek 2004). Osmanlı hükümeti, bu meselelerin Avrupalı devletlerin müdahalesine açık hale gelmemesi için özel bir çaba sergiliyordu. Bunun için de iç gü- venliğin sağlanması zorunluluk olarak görülüyordu.

Seyahatlerle ilgili düzenlemelerde olduğu gibi otel ve misafirhanelere dair düzenlemelerin temelinde de güvenlik endişesi vardı. Hükümet, başta İstanbul olmak üzere Osmanlı şehirlerine gelen yabancı turistler arasinda devlet aleyhinde birtakım zararlı faaliyetlerde bulunanlar olduğunu düşünüyor ve bunların kayıt altına alınarak tespit edilmeleri noktasında daha fazla özen gösterilmesini istiyordu. Zabtiye Nezareti'ne gönderilen yazıda; İstanbul'a gelerek otel ve misafirhanelerde konaklayan turistlerin isim, şöhret, eşkâl ve geliş tarihlerinin belirlenmesi için konaklama yerlerinin sahipleri tarafından birer defter tutulması gerektiği belirtiliyordu. Ayrıca otel ve misafirhane sahiplerinin, hal ve hareketlerinden şüphe ettikleri birisi ile karşılaştıklarında derhal durumu en yakın polis müdüriyetine bildirmesi noktasında kendilerinin tembih edilmesi isteniyordu. Bununla birlikte güvenlik güçlerinin istasyonlar, meydanlar ve turistik merkezler gibi kalabalık yerlerde daha dikkatli davranmaları ve aylık olarak ne kadar turistin gelip gittiğini gösteren bir istatistik defteri tutmaları gerektiği ifade ediliyordu (BOA. DH. MKT., 1819/46; BOA. DH.MKT., 1794/69, 1 Kanunuevvel 306/13 Aralık 1890).

Bir başka belgede, Avrupa'dan İstanbul'a çok sayıda yabancının gelmekte olduğu, bunlar arasında çeşitli suçlardan ve hatta cinayetten mahkûm bulunan birtakım kimselerin dahi bulunduğu belirtiliyordu. Bu gibi kişilerin sabıka-i halleri bilinemediğinden haklarında herhangi bir işlem yapılamadığı ve Osmanlı topraklarında rahatça gezinebildikleri ifade ediliyordu. Hatta Dorini isminde bir diş doktorunun Paris'te cinayet suçundan aranırken firar ederek İstanbul'a geldiği, burada özel diş doktorluğu yapmaya devam ettiği ve bu yolla şöhret kazandığı bildiriliyordu. Dahası bu kişinin II. Abdülhamit'in dişçibaşılık hizmetine dahi alındığı, ancak vefatından sonra gerçek durumun ortaya çıktığı belirtiliyordu. Bundan dolayı İstanbul'a gelerek otel ve misafirhanelerde konaklayanların durumlarının tespit ve takip edilebilmesi için işletme sahipleri tarafından düzenli olarak kayıt defterleri tutulması 
ve hükümet tarafından bunların tetkik edilmesinin zorunluluk olduğu vurgulanıyordu (BOA. İ.DH., 1008/79628, 11 Safer 304/9 Kasım 1886). Görüldüğü üzere bu dönemde otel ve misafirhanelere dair düzenlemelerin temelinde güvenlik endişesi vardı. Osmanlı topraklarına gelerek otel, misafirhane, han gibi konaklama yerlerinde kalanların tespit edilerek kayıt altına alınması düşüncesi bu konuda birtakım yasal düzenlemelerin yapılmasını zorunlu kilıyordu. Bu doğrultuda çalışmalarını şekillendiren hükümet, Zaptiye Nezareti ve İstanbul Polis Müdüriyet-i Umumiyesi'nin de görüşlerine başvurarak gerekli yasal düzenlemeleri hayata geçirmeye çalıştı.

\section{Otel ve Misafirhanelere Dair Düzenlemeler}

Osmanlı Devleti'nde otel ve misafirhanelere dair ilk çalışma 1887 yılında polis müşaviri Mösyö Bunt tarafından kaleme alınmış olan "Dersaâdet ve Bilâd-1 Selâse'de Bulunan Otel ve Misafirhâneler Hakkında Talimattır" başlıklı düzenlemedir. İstanbul ve çevresindeki konaklama faaliyetlerini kontrol altında tutmak ve bunlara düzen vermek maksadıyla hazırlanan talimat 11 maddeden oluşmaktadır (BOA. ŞD., 2568/9, 8 Receb 304/2 Nisan 1887). Söz konusu talimata göre; otel açmak ya da evinin odalarını kiralamak isteyenler öncelikle polis idaresine bilgi vereceklerdir. Otel ve misafirhanelerin tespiti için kapıları üzerine birer levha konulacaktır. Konaklama yerlerinin kısmen mi yoksa bütünün mü kiraya verileceği kapıya asılacak levhalarda gösterilecektir (1-3. maddeler).

Otel ve misafirhane sahipleri Ceza Kanunu'nun 254. maddesinde belirtilen esaslara uygun şekilde hareket edeceklerdir. İşletme sahipleri tarafından misafirlerin hangi ülkeden geldikleri, isim, şöhret, sanat, ticaret ve tabiiyetlerini belirten bir kayıt defteri tutulacaktır. Bu defterde konaklayanların ülkeye ne zaman giriş yaptıkları ve odayı hangi tarihte kiraladıkları yazılı olacak olup hiçbir suretle üzerinde herhangi bir silinti yapılmayacaktır. Bu kaideye uygun davranmayan işletme sahiplerine beş beşlikten yirmi beşliğe kadar para cezası verilecektir. Söz konusu kayıt defterinde işletme sahiplerinin adı, şöhreti, tabiiyeti, işletmenin bulunduğu mahal ve açılış tarihi yazılı olacaktır (4 ve 5 . maddeler).
Kayit defterlerini eksik dolduran veya yanlış kaydeden ya da otel ve misafirhanelere gelenlerin şüpheli kişiler olduğunu görüp de polise haber vermeyen işletme sahipleri, sahte pasaport gibi sahte evrak düzenleyenler hakkında uygulanacak cezaya çarptırılacaklardır. Güvenlik açısindan gereksinim duyulduğu takdirde otel ve misafirhanelerde konaklayanların isimlerinin kaydedildiği defterler incelenmek üzere polis tarafından talep olunabilecektir. Bu durumda işletme sahipleri kayit defterlerini polislere teslim edecek ve bunlar 24 saat süreyle polis idaresinde incelenebilecektir. Kayıt defterlerini incelemeye memur olan polisler, otel ve misafirhanelerde ikamet edenlerle buradan ayrilanların isimlerini özel bir deftere kaydedeceklerdir (6-8. maddeler).

Çeşitli suçlardan aranan ya da şüpheli olarak görülen şahısların otel ve misafirhane gibi konaklama yerlerinde gizlendikleri düşünüldüğü takdirde polisler tarafından söz konusu işletmelerde arama yapılabilecektir. Eğer suçlu ya da şüphelilerin gizlendikleri düşünülen işletme yabancı uyruklu birisine ait ise bu husustaki kanuna uygun olarak polis idaresi tarafindan arama gerçekleştirilecektir. Polis memurları konaklama yerlerini dolaşıp inceleme ve arama yapacak, edep ve asayişi ihlal eden kişileri tevkif edecektir. Polis memurları tabi oldukları kanun ve talimata uygun olarak yürütecekleri tahkikatı jurnal ile merkeze bildireceklerdir. Bu hususta kanuni takibat polis meclisi ve savcılık makamı tarafından ifa edilecektir. Bu talimatın icrası Dâhiliye Nezareti tarafından gerçekleştirilecektir (9-11. maddeler).

Görüldüğü üzere polis müşaviri Mösyö Bunt tarafından kaleme alınan otel ve misafirhaneler hakkındaki talimat temelde güvenlik zafiyetinin giderilmesi ve asayişin sağlanması esasına dayanıyordu. Söz konusu talimatname Şûra-yı Devlet Tanzimat Dairesi tarafından incelenmiş ve üzerinde birtakım tadilat yapılmasının gerekli olduğu kanaatine varılmıştır. Buna göre; Avrupa'dan İstanbul'a gelen ve sabıka-i halleri bilinmeyen pek çok yabancının birtakım sanat ve hizmetle burada yerleşip kalmalarının iktisadi ve siyasi açıdan devleti zarara uğrattığ ${ }_{1}$ belirtiliyordu. 
Bu tarz kimselerin durumlarının tetkik edilmesi gerektiğinin Polis Nizamnamesi'nde belirtildiği, ayrıca Pasaport Nizamnamesi'nde de Osmanlı topraklarına gelecek yabancıların mürur tezkereleriyle pasaportlarının dikkatle incelenmesinin zorunlu olduğunun kaydedildiği ifade ediliyordu. Bu doğrultuda söz konusu talimatta belirtildiği üzere otel ve misafirhanelerde konaklayanlardan şüpheli görülenlerin soruşturulması için işletmelerde arama yapılmasının kanuna uygun olduğu belirtiliyor ve yabancı elçiliklerin bu hususta herhangi bir engel çıkaramayacağ 1 vurgulanıyordu. Ancak yabancı vatandaşlardan evinin bir veya birkaç odasını kiraya verenlerin evlerine polis memurlarının girmesine elçilikler tarafından engel çıkarılabileceği belirtilerek bu noktanın tadil edilmesi gerektiği beyan ediliyordu (BOA. ŞD., 2568/9, 8 Receb 304/2 Nisan 1887).

Bununla birlikte otel ve misafirhanelere dair talimatın mümkün mertebe Avrupa ülkelerinde uygulanan usule uygun olması gerektiği belirtiliyordu. Bu doğrultuda talimatta belirtilen hükümlere uygun olarak hareket etmeyenler hakkında verilecek cezaların belirlenmesinde hukuk müşaviri Kapril Efendi'nin görüşlerine başvurulması gerektiği ifade ediliyordu. Mösyö Bunt'un sunduğu layihanın memleketin durumuna uygun olmayacak bazı ağır cezalar içerdiği belirtilerek bunların uygulamaya konulmasının mümkün olamayacağı beyan ediliyordu. Bu noktadan hareketle söz konusu talimatın Osmanlı Devleti'nin durumu ve idari esasları göz önünde bulundurulmak suretiyle Pasaport Nizamnamesi ile kararlaştırılan kanuna uygun şekilde tadil edilmesi gerektiği vurgulanıyordu. Ayrıca işletme sahipleri tarafından tutulacak kayıt defterlerine konaklayanların ismini kaydetmeyen veya yanlış kaydeden ya da şüpheli birisini görüp de polise haber vermeyenler hakkında sahte pasaport veya sahte evrak düzenleyenler ile ilgili ceza maddesi dairesinde işlem yapılacağının belirtildiği ifade ediliyordu. Ancak bu hususta Pasaport Nizamnamesi'nin 155. maddesinde zikredildiği üzere sahte evrak düzenleyenlerin hapis cezası ile cezalandırılacağının beyan edildiği vurgulanarak söz konusu talimatın da bu kaideye uygun olarak düzenlenmesi gerektiği belirtiliyordu (BOA. ŞD., 2568/9, 8 Şaban 304/2 Mayıs 1887).
Mösyö Bunt'un hazırladığı talimat üzerinde yapılması istenen değişikliklerin kısa sürede hayata geçirilmesi mümkün olmamıştır. Belirlenen düzenlemelerin yapılması yıllar almış, yaklaşık dört yıl sonra meselenin sonuçlandırılması için yeni bir adım atılmıştır. Bu kapsamda talimat üzerinde gerekli tadilatı yapmak maksadıyla Zabtiye Nezareti'nde bir komisyon oluşturulmuştur. Söz konusu komisyonun yürüttüğü çalışmalar neticesinde talimatta belirtilen bazı noktalarda değişiklik yapılması öngörülmüştür. Dördüncü maddede yapılan değişikliğe göre; otel ve misafirhanelerde konaklayanların kayıtlarının tutulacağ defterlerin hem Türkçe hem de Fransızca olarak hazırlanacağı hususu eklenmiştir. Ayrıca talimatta belirtilen yükümlülükleri yerine getirmeyen işletme sahiplerine verilecek para cezası caydırıcı olmaz ve suç üç defa tekrar edilecek olursa belirli bir süre için işletmenin kapatılaca$\breve{g}_{1}$ belirtilmiştir (BOA. ŞD., 2568/9, 23 Şubat 306/7 Mart 1891). Otel ve misafirhanelere dair talimat üzerinde yapılacak tadilat Hariciye Nezareti İstişare Odası'nda da görüşülmüş ve birtakım öneriler ileri sürülmüştür. Buna göre; Osmanlı Ceza Kanunu'nun 256. maddesinde hanc1 ve lokantacılar gibi odalarını kiraya verenlerin bir kayıt defteri tutmaları gerektiği belirtilmiştir. Bu hususta gösterecekleri ihmalden dolayı kendilerine altı beşlikten on beşliğe kadar para cezası verilmesinin öngörüldüğü beyan edilmiştir. Bu noktadan hareketle otel ve misafirhanelerde konaklayanların kayıtlarını düzenli olarak tutmayan işletme sahiplerine de beş beşlikten yirmi beşliğe kadar para cezası yerine altı beşlikten on beşliğe kadar para cezası verilmesinin daha uygun olacağı ifade edilmiştir. Ayrıca talimatnamede belirtilen bazı hususların polis talimatnamesine de eklenmesi gerektiği bildirilmiştir (BOA. ŞD., 2568/9). Ancak teklif edilen bu düzenlemeleri uygulamaya koymak ve talimatı yayınlamak mümkün olmamış, çalışmaların sonuçlandırılması ve talimatın yayınlanması için 1895 yılına kadar beklemek gerekmiştir.

Osmanlı Devleti'nde otel ve misafirhaneler ile ilgili olarak ilk kez 1887 yılında Mösyö Bunt'un başlattığı girişimin sonuçlandırılması yıllar almıştır. Hariciye, Dâhiliye ve Zabtiye Nezaretleri, İstanbul Polis Müdüriyeti ve Şûra-yı Devlet da- 
iresinde oluşturulan komisyonların yürüttüğü çalışmalar neticesinde konuyla ilgili esaslar belirlenmiş ve 1895 senesinde "Dersaâdet ve Bilâd-1 Selâse'de Bulunan Otel ve Misafirhâneler Hakkında Talimattır" başlığıyla 9 maddelik bir talimat çıkarılmıştır (Düstûr 1335: 187-188; Düstûr 1939: 1565-1566; BOA. HR. İD., 178/43, 14 Ramazan 312/11 Mart 1895; BOA. HR.HMŞ.IŞO., 60/26, 14 Ramazan 312/11 Mart 1895).

Söz konusu talimata göre; otel açacaklar ya da hanesinin odalarını kiraya verecekler öncelikle polis idaresine bilgi vereceklerdir. Otel ve misafirhanelerin bilinmesi için kapıları üzerine birer levha konulacaktır ( 1 ve 2 . maddeler). Otel ve misafirhane sahipleri Ceza Kanunu'nun 254 ve 256. maddelerinde belirtilen kaidelere göre hareket etmeye mecbur olacaklardır. İşletme sahipleri misafirlerin hangi ülkeden geldikleri, isim, şöhret, sanat, ticaret ve tabiiyetlerini belirten bir polis defteri tutulacaklardır. Bu defterde konaklayanların ülkeye ne zaman giriş yaptıkları ve odayı hangi tarihte kiraladıkları yazılı olacak olup hiçbir suretle üzerinde herhangi bir silinti yapılmayacaktır. Bu kaideye uygun davranmayan işletme sahiplerine altı beşlikten on beşliğe kadar para cezası verilecektir. Polis defterlerinde işletme sahiplerinin isim, şöhret, doğum tarihi ve yeri, tabiiyeti, işletmenin açılış tarihi gibi bilgiler kayıtlı olacaktır (3 ve 4 . maddeler).

Şüpheli görülen şahısları polise haber vermeyen işletme sahipleri Ceza Kanunnamesi'nin sahtekârlığa dair olan 15. faslında belirtilen hükümlere göre cezalandırılacaktır. Polisler kendilerince gerekli gördükleri takdirde otel ve misafirhanelere gelen yolcuların bilgilerinin kaydedildiği defterleri inceleyecek ve polis idaresi istediği zaman bu defterleri merkeze götürebilecektir (5 ve 6 . maddeler). Defterlerin incelenmesine memur olan polisler otel ve misafirhanelerde ikamet edenlerin ve buradan ayrilanların isimlerini ayrı bir deftere kaydedeceklerdir. Çeşitli suçlardan dolayı şüpheli ya da mahkûm olanlar ile serseri takımından olduğu belirtilen kişilerin otel ve misafirhanelerde gizlendikleri düşünüldügü takdirde buralarda arama yapılabilecektir. Arama yapilacak otel veya misafirhanenin sahibi yabancı uyruklu ise bu husustaki kanuna uygun olarak polis idaresi tarafından arama gerçekleştirilecektir. Söz konusu talimatın uygulanmasına Dâhiliye Nezareti memur olacaktır (7-9. maddeler).

Görüldüğü üzere İstanbul ve çevresindeki konaklama faaliyetlerini kontrol altında tutmak ve bunlara düzen vermek maksadıla yapılan yasal düzenlemelerin temelinde güvenlik endişesi yatıyordu. Yaklaşık sekiz yıllık çalışmanın sonucunda edinilen birikim ile kaleme alınan talimatın maddelerine bakıldığında Mösyö Bunt'un Fransa'daki benzer uygulamaları esas alarak 1887 yılında hazırladığı taslakla büyük oranda örtüştüğü görülmektedir. Bununla birlikte hukuki kaidelerin daha net esaslarla belirlendiği, bu husustaki maddelerin Ceza Kanunnamesi hükümlerine uygun hale getirildiği tespit edilmektedir.

\section{Otel ve Misafirhanelere Dair Talimatın Uygulanması ve Ortaya Çıkan Sorunlar}

Öncelikle belirtmek gerekir ki 1895 yılında yürürlüğe konulan talimat hükümleri yalnızca İstanbul ve çevresindeki konaklama yerlerini kapsıyordu. Söz konusu talimat ülkenin diğer bölgelerinde uygulamaya konulmamıştır. Zira bu dönemde Osmanlı topraklarında bulunan otel ve misafirhane gibi konaklama hizmeti veren işletmelerin büyük çoğunluğu İstanbul ve çevresinde konuşlanmıştır. Bunun yanı sıra sayıları oldukça sınırlı olmakla birlikte İzmir, Selanik, Samsun gibi liman kentlerinde de çeşitli nitelikte konaklama hizmeti veren işletmeler bulunuyordu (Çiçek 2006; Ertuğrul 2009; Sarısakal t.y.).

Otel ve misafirhanelere dair düzenlemelerin uygulanmaya konulmasında birtakım sorunlar ortaya çıkmıştır. Otel ve misafirhane gibi konaklama tesisi işleten gayrimüslim işletme sahiplerinin birçoğu işletmelerinde konaklayan müşterilerin bilgilerini güvenlik birimleriyle paylaşmak istememişlerdir. Genellikle söz konusu düzenlemenin kendilerine tebliğ edilmediğini gerekçe göstererek ilgili talimatın uygulanmasına karşı çıkmışlar, bu konuda bağlı bulundukları sefaretlerce de desteklenmişlerdir. Örneğin; Avusturya vatandaşı olup İstanbul'da Komersiyal adlı bir otel işletmekte bulunan Koçu İvanovic, otelde konaklayanların kimlik bilgilerini güven- 
lik birimlerine vermediği gerekçesiyle hakkında işlem başlatılarak mahkemeye sevk edilmiştir. İvanovic, mahkemedeki savunmasında Avusturya Sefareti'nin isteği doğrultusunda müşterilerin kimlik bilgilerini polise vermediğini ifade etmiştir. Mahkemede hazır bulunan konsolosluk tercümanlarından Mösyö Alfred Lazard, otel ve misafirhanelere dair talimatın sefarete tebliğ edilmediği gerekçesiyle Avusturya vatandaşlarına söz konusu talimat hükümlerini uygulamamaları gerektiğinin söylendiğini belirtmiştir. $\mathrm{Bu}$ nun üzerine söz konusu kanunun sefarete tebliğ edilip edilmediğinin soruşturulmasına karar verilmiştir (BOA. HR. İD., 178/64, 28 Safer 1332/26 Ocak 1914). Bu meseleyle ilgili olarak Hariciye Nezareti'nden Adliye Nezareti'ne gönderilen cevap yazısında; ilgili talimatın sefaretlere bildirildiği, ayrıca Takvim-i Vekayi'nin 10 Mart 1328 tarih ve 1081 numaralı nüshasında yayınlanmış olduğunun Fransa, İngiltere, Avusturya, Almanya ve Rusya sefaretlerine tebliğ edildiği ifade edilmiştir (BOA. HR. İD., 178/64). Bu meseleye dair görülen dava neticesinde İvanovic'e bir lira para cezası verilmiş ancak kendisi mahkemenin kararına itiraz ederek davayı bir üst mahkemeye taşıdığından karar uygulanamamıştır. Benzer gerekçelerle Pera'da bulunan Continental Otel'in işletmecisi Fransız vatandaşı Jaime Agustin hakkında da dava açılmıştır. Mahkemeye çıkmayı reddeden Agustin'e bir lira para cezası verilmiş ancak giyaben verilen bu mahkûmiyete dair tebligat kendisine ulaştırılamadığından dolayı cezanın icrasına geçilememiştir (BOA. HR. İD., 178/67, 14 Receb 332/8 Haziran 1914).

İzmir'de Çanak Sokağı'nda bulunan 6 numaralı evinin odalarını kiraya vermek suretiyle işleten İtalyan vatandaşı Madam Lori Makrepo, evinde konaklayanların kimlik bilgilerini ibraz etmediği ve talimatnamede belirtildiği üzere evinin kapısına bir levha koymadığ 1 gerekçesiyle şikâyet edilmiştir. Bu hususta Aydın Birinci Ceza Mahkemesi'nce yürütülen davaya katılması için Madam Makrepo'ya celpname gönderilmiş ancak söz konusu tebligat İtalyan konsolosluğu tarafından kendisine bir türlü bildirilmemiştir. Bundan dolayı sefaret nezdinde teşebbüste bulunularak sorunun giderilmesi istenmiştir (BOA. HR. İD., 178/65, 25 Rebiülâhir 332/23 Mart 1914).

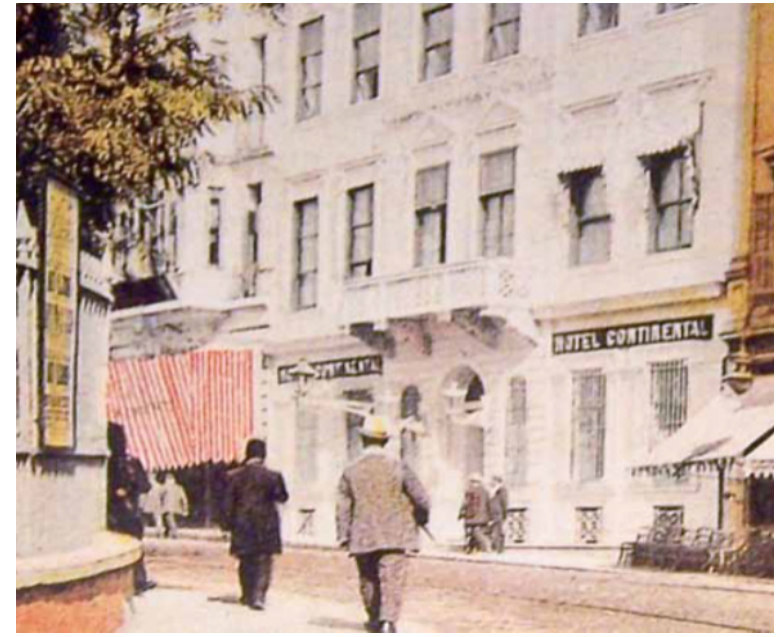

Fotoğraf 2. Continental Otel, Pera (Yakartepe ve Binan 2011).

İzmir'de Çanak Sokağı'nda bulunan 6 numaralı evinin odalarını kiraya vermek suretiyle işleten İtalyan vatandaşı Madam Lori Makrepo, evinde konaklayanların kimlik bilgilerini ibraz etmediği ve talimatnamede belirtildiği üzere evinin kapısına bir levha koymadığı gerekçesiyle şikâyet edilmiştir. Bu hususta Aydın Birinci Ceza Mahkemesi'nce yürütülen davaya katılması için Madam Makrepo'ya celpname gönderilmiş ancak söz konusu tebligat İtalyan konsolosluğu tarafından kendisine bir türlü bildirilmemiştir. Bundan dolayı sefaret nezdinde teşebbüste bulunularak sorunun giderilmesi istenmiştir (BOA. HR. İD., 178/65, 25 Rebîülâhir 332/23 Mart 1914).

Görüldügü üzere otel ve misafirhanelerle ilgili düzenlemenin hükümlerine karşı genellikle otel ve misafirhane işleten gayrimüslim Osmanlı tebaası tarafından birtakım karşı duruşlar olmuştur. Bunlar işletmelerinde konaklayan misafirlerin bilgilerini devlet birimleriyle paylaşmak istememişlerdir. Bu konuda bağlı bulundukları sefaretlerce de desteklenmişler, söz konusu düzenlemenin uygulanmasını önlemeye çalışmışlardır. Bundan dolayı hükümet sık sık sefaretlere yazı göndererek uyarılarda bulunmuş ve gayrimüslim işletme sahiplerinin bilgilendirilmesini istemiştir. Hükümetin ilgili birimlere gönderdiği yazılarda; otel ve misafirhanelerde konaklayanların kayıtlarının düzenli olarak tutulması gerektiği vurgulanmıştır. Bu hususta gayrimüslim Osmanlı tebaası veya yabancı devlet vatandaşları 
tarafından işletilen işletmelerce istenilen özenin gösterilmesi ve güvenlik birimlerine zorluk çıkarılmayarak talep edilen bilgilerin paylaşılması gerektiği bir kez daha yabancı sefaretlere bildirilmiştir (BOA. HR. İD., 178/52, 19 Zilhicce 1329/11 Aralık 1911). Buna rağmen bu konudaki sorunları bütünüyle çözüme kavuşturmak mümkün olamamıştır.

\section{ÖNERILER VE SONUÇ}

Ülkemizde turizmin tarihsel gelişimi üzerine yapılmış muhtelif çalışmalar bulunmakla birlikte Osmanlı Devleti'nde turizmin gelişimi, bu alanda devlet ve özel teşebbüs tarafından yapılan yatırımlar, otel ve konaklama merkezleri ve rehberlik gibi turizmle ilgili konularda hükümetin gerçekleştirdiği yasal düzenlemeler, seyahat için yurtdışına çıkan Osmanlı vatandaşları ile seyahat maksadıyla Osmanlı ülkesine gelen yabancı devlet vatandaşlarının sayısının ne kadar olduğu, dolayısıyla dünya turizmi içinde Türk turizminin hangi noktada yer aldığ́1 gibi meseleleri açıklayan kapsamlı araştırmalar oldukça azdır. Söz konusu meseleleri bütüncül bir yaklaşım çerçevesinde ele alacak ve Türk turizminin dünya turizmi içindeki yerinin tespit edilmesine katkı sunacak çalışmalara ihtiyaç vardır. Bu noktadan hareketle yakın zamanda alanında uzman bir araştırma grubu ile birlikte tarafimızca bu meselelerin tespitine yönelik olarak kapsamlı bir araştırma projesi yapılması planlanmaktadır.

Sanayi Devrimi ile birlikte yaşanan bilimsel ve teknolojik gelişmeler dünyada turizmin gelişimini sağlayan en önemli etmenler olmuştur. Özellikle ulaşım alanında yaşanan teknolojik gelişmelerin ardından buharlı gemiler ve demiryollarının ulaşım aracı olarak kullanılmaya başlanmasıyla seyahat süreleri kısaldı̆̆ı gibi giderler de önemli oranda azalmıştır. Bu durum daha fazla sayıda insana seyahat etme imkânı tanımıştır. Ülkeler arası seyahat sürelerinin kısalması ve masrafların azalmasıyla birlikte giderek daha fazla sayıda insan turistik amaçlarla seyahat etmeye başlamıştır. Bununla birlikte özellikle Avrupa'da XIX. yüzyılda güçlü ekonomik yapıya sahip bir orta sınıfın oluşumu ve bu kitlenin her geçen gün daha fazla turistik seyahatlere yönelmeye başla- mış olması turizmin gelişimi noktasında önemli bir adım olmuştur. Fransız İhtilali sonrasında kişisel hak ve özgürlüklerin gelişmesi ve buna bağlı olarak da seyahat özgürlüğü ve güvencesinin verilmesi turistik amaçlarla yapılan seyahat sayısının artmasında başlıca etmenlerden biridir. Bu gelişmeler zamanla dünyada bir turizm pazarının oluşmasına neden olmuştur. Bunun üzerine ilki 1841 yılında Thomas Cook tarafından kurulan seyahat acentesi olmak üzere Londra, Paris, Viyana gibi Avrupa başkentlerinde sayısız seyahat acentesi tesis edilmiştir. Bu kuruluşlar turlar düzenleyerek daha fazla insana seyahat etme imkânı sunmuşlardır.

Özellikle XIX. yüzyılın ikinci yarısından itibaren turizmin ekonomik bir pazar yaratmasıyla birlikte İngiltere, İtalya, İsviçre gibi birçok Avrupa ülkesi bu alanda yatırımlar yapmaya başlamışlardır. Bu doğrultuda Batılı devletler, Londra, Paris, Viyana gibi çeşitli Avrupa başkentlerinde düzenlenen sergi ve fuarlar aracılı̆̆ıyla kendi ülkelerini tanıtmaya ve turizm pazarında daha büyük bir alan edinmeye çalışmışlardır. Bu noktada 1863 yılında İstanbul'da düzenlenen Sergi-i Umumi-i Osmani, Osmanlı Devleti'nin de kendi ülkesinin reklamını yapmaya ve artık bir pazar haline gelen turizm alanında yer edinmeye çalıştığını göstermektedir. Zira bu dönemden itibaren özellikle Avrupa'dan, Osmanlı topraklarını ziyaret etmek için giderek daha fazla sayıda insan gelmeye başlamıştır. Ayrıca Osmanlı toprakları ticari ve dinî açıdan da büyük turizm potansiyeline sahiptir. Osmanlı Devleti, Mekke, Medine, Kudüs gibi üç büyük dine inananlar için kutsal kabul edilen şehirleri elinde bulunduruyor olması nedeniyle tüm dünyadan ziyaretçi çekmiştir. Doğu-Batı ticareti açısından bir köprü vazifesi görüyor olması nedeniyle Osmanlı toprakları daima ticaret amaciyla seyahat edenlere de ev sahipliği yapmıştır.

Turizm alanında yaşanan gelişmelerin etkisiyle Osmanlı topraklarına yönelen turist sayısının artmasına paralel olarak XIX. yüzyılın ikinci yarısından itibaren başta İstanbul olmak üzere turizm potansiyeline sahip Osmanlı şehirlerinde daha fazla sayıda konaklama, yeme-içme ve eğlence merkezleri inşa edilmeye başlanmıştır. Bu 
doğrultuda yerli ve yabancı girişimcilerin yatırımlarıyla özellikle İstanbul ve İzmir gibi liman kentlerinde otel ve konaklama yerlerinin sayısı hızla artmıştır. Bunun üzerine otel ve konaklama yerlerine dair birtakım yasal düzenlemelerin yapılması zorunluluk haline gelmiştir. Gerek bunların kuruluşu ve işletmesi gerekse konaklayacak turistlerin kayıt altına alınması ihtiyacinı karşılamak adına bazı düzenlemeler yapılmıştır. Bu doğrultuda 1887 yılında, İstanbul ve çevresindeki konaklama faaliyetlerini kontrol altında tutmak ve bunlara düzen vermek maksadıyla “Dersaâdet ve Bilâd-ı Selâse'de Bulunan Otel ve Misafirhâneler Hakkında Talimattır" başlıklı 11 maddelik bir düzenleme ortaya konulmuştur. Fransa'daki benzer örnekleri esas alınarak polis müşaviri Mösyö Bunt tarafından hazırlanarak hükümete sunulan tasarı niteliğindeki talimat, bu alanda yapilacak olan yasal düzenlemelerin temelini oluşturmaktadır. Ancak söz konusu talimatın tamamlanarak yürürlüğe konulması için uzun süre beklemek gerekmiştir. Bu alanda yürütülen çalışmalara katkı vermek ve meseleyi çözüme kavuşturmak için Hariciye, Dâhiliye ve Zabtiye Nezaretleri, İstanbul Polis Müdüriyeti ve Şûra-yı Devlet dairesinde komisyonlar oluşturulmuştur. Bunların yürüttüğü çalışmalar neticesinde konuyla ilgili esaslar belirlenmiş ve 1895 senesinde "Dersaâdet ve Bilâd-1 Selâse'de Bulunan Otel ve Misafirhâneler Hakkında Talimattır" başlığıyla dokuz maddelik bir talimat çıkarılmıştır.

Söz konusu talimat incelendiğinde; bu dönemde otel ve misafirhanelere dair yapılan düzenlemelerin temelinde güvenlik endişesinin yattığ görülmektedir. Osmanlı hükümeti ülkeye giriş çıkışları sıkı bir şekilde kontrol altında tutmaya ve çeşitli amaçlarla Osmanlı ülkesine gelen kişileri kayıt altına almaya çalışmıştır. İktidarın iç güvenliği sağlamaya yönelik adımlarının ve bu konudaki endişesinin temelinde devletin içinde bulunduğu hassas siyasi durum önemli bir yer tutmaktadır. Zira bu dönemde Doğu Anadolu'da "Ermeni Meselesi" ve Balkanlar'da "Makedonya Meselesi" Osmanlı siyasetinin merkezini oluşturmaktadır. Avrupalı devletler ise bu bölgelerde ortaya çıkabilecek herhangi bir karışıklığı kendi politikaları çerçevesinde değerlendirmek için hemen söz konusu topraklara ve Osmanlı siyaseti- ne müdahale ettiklerinden hükümet bu konuda son derece hassas davranmaktadır. Bu nedenle hükümet ülke içinde herhangi bir karışıklığa sebebiyet verebilecek kişileri önceden tespit etmek, dolayısıyla iç güvenliği sağlamak için ülkeye gelen turistlerin kayıt altına alınmasını zorunluluk olarak görmektedir. Bu dönemde otel ve misafirhanelerle ilgili olarak yapılan düzenlemelerin temelinde de bu düşünceler yatmaktadır.

\section{KAYNAKÇA}

Arşiv Kaynakları

1. Başbakanlık Osmanlı Arşivi (BOA)

Dâhiliye Nezareti Evrakı

Dahiliye Nezareti Mektubî Kalemi (DH.MKT), No: 386/73; 1794/69; 1819/46.

Hariciye Nezareti Evrakı

Hariciye Nezareti İdare (HR.İ), No: 178/43; 178/52; 178/64; $178 / 65 ; 178 / 67$.

Hariciye Nezareti Hukuk Müşavirliği İstişare Odası Evrakı (HR.HMŞ.IŞO), No: 60/26.

İrade Tasnifi

İrade Dâhiliye (İ.DH), No: 1008/79628.

İrade Meclis-i Vâlâ (İ.MVL), No: 529/23721.

Maarif Nezareti Evrak1

Mektubi Kalemi (MF.MKT), No: 388/52.

Şûra-yı Devlet Evrakı

Şûra-yı Devlet (ŞD), No: 2568/9.

\section{Resmî Yayınlar ve Gazeteler}

Düstûr, Dersaadet ve Bilâd-1 Selâse'de Bulunan Otel ve Misafirhaneler Hakkında Talimattır, 1. Tertip, Cilt: 6, Ankara Devlet Matbaası, 1939: 1565-1566.

Düstûr, Dersaadet ve Bilad-1 Selasede Bulunan Otel ve Misafirhaneler Hakkında Talimat, 1. Tertip, Cilt: Mütemmim, Hilal Matbaas1, 1335: 187-188.

Takvim-i Vekayi, No: 1081.

Araştırma ve İncelemeler

Akyıldız, A. (2005). Anka'nın Sonbaharı Osmanlı'da İktisadî Modernleşme ve Uluslararası Sermaye. İstanbul: İletişim Yayinlari.

Baykara, T. (2010). Tarih Araştırma ve Yazma Metodu. İstanbul: IQ Kültür Sanat Yayıncilik.

Cebeci, S. (2002). Bilimsel Araştırma ve Yazma Teknikleri. İstanbul: Alfa Yayınları.

Çadırcı, M. (1993). Tanzimat Döneminde Çıkarılan Men-i Mürûr ve Pasaport Nizâmnâmeleri, Belgeler, 15 (19): 169-185.

Çetin, E. (2017). Osmanlı Turizm Tarihinden Kesitler: Ernest Arman'1n Seyahat Acentesi Kurma Girişimleri, Uluslararası Avrasya Sosyal Bilimler Dergisi, 30: 1491-1512. 
Çiçek, Ü. (2006). İzmir Konaklama Yapıları ve Tarihsel Gelişimi. İzmir Ticaret Odası http://www.izto.org.tr/Portals/0/ izmirde_konaklama_yapilari_ve_tarihsel_gelisimi.pdf, Erişim tarihi: 11 Ağustos 2017.

Eralp, Z. (1983). Genel Turizm. Ankara: Ankara Üniversitesi, Basın-Yayın Yüksek Okulu Yayınları: 3.

Ertuğrul A. (2009). XIX. Yüzyılda Osmanlı'da Ortaya Çıkan Farklı Yapı Tipleri, Türkiye Araştırmaları Literatür Dergisi, 7(13): 293-312.

Kanca, H. (2013). XIX. Yüzyılın İkinci Yarısında Uluslararası Osmanlı Fuarı: 1863-Sergi-i Umumi-i Osmanî, Accounting \& Financial History Research Journal, 5: 159-187.

Karasar, N. (2016). Bilimsel Araştırma Yöntemi: Kavramlar Illkeler Teknikler. Ankara: Nobel Akademik Yayıncllık.

Kozak, M. (2017). Bilimsel Araştırma: Tasarım, Yazım ve Yayım Teknikleri. Ankara: Detay Yayıncilık.

Kozak, N., Kozak, M.A., Kozak, M. (2000). Genel Turizm Illkeler-Kavramlar. Ankara: Turhan Kitabevi.

Kurmuş, O. (2012). Emperyalizmin Türkiye'ye Girişi. İstanbul: Yordam Kitap.

Kütükoğlu, M. S. (2014). Tarih Araştırmalarında Usûl. Ankara: Türk Tarih Kurumu Yayınları.

Nance, S. (2007). A Facilitated Access Model and Ottoman Empire Tourism, Annals of Tourism Research, 34 (4): 1056-1077.

Olalı, H.-Timur, A. (1988). Turizm Ekonomisi. İzmir: Ofis Ticaret Matbaacilik.

Önsoy, R. (1983). Osmanlı İmparatorluğu'nun Katıldığı İlk Uluslararası Sergiler ve Sergi-i Umumi-i Osmani (1863 İstanbul Sergisi), Belleten, XLVII (185): 195-235.

Özbek N. (2004). Osmanlı İmparatorluğu'nda İç Güvenlik, Siyaset ve Devlet, 1876-1909, Türklük Araştırmaları Dergisi, 16: 59-95.

Özdemir, M. (2011). Türkiye'de Turizmin Başlaması: Osmanlı'da Sanayileşme Çabaları: Sergi-i Umumi-i Osmanî (1863 İstanbul Uluslararası Sergisi), Anatolia: Turizm Araştırmaları Dergisi, 22 (1): 87-90.

Sander, O. (1973). Tarihte Yöntem, Ankara Üniversitesi Siyasal Bilgiler Fakültesi Dergisi, 28 (1): 59-71.

Sarısakal, B. (t.y.). Samsun'un Tarihi Otelleri (1880-1938), http:// www.bakisarisakal.com/SAMSUN\%20OTEL.pdf, Erişim tarihi: 11 Ağustos 2017.

Togan, Z. V. (1985). Tarihte Usûl. İstanbul: Enderun Kitabevi.

Toprak, Z. (1993). 'Seyyah'tan 'Turist'e, 'Sinâat'tan 'Endüstri'ye: "Ecânib Sinâatı," (Türkiye'e 'Ecânib Sinâatı' ya da 'Turizm Endüstrisi'). İstanbul Tarih Vakfı Yayını, 6: 66-69.

Turna, N. (2014). Osmanlı İstanbulu'nda İç Pasaport: Mürûr Tezkeresi. İçinde F. M. Emecen, A. Akyıldız ve E. S. Gürkan (Editörler), II. Uluslararası Osmanlı İstanbulu Sempozyumu Bildirileri, (ss. 389-403). İstanbul: İstanbul 29 Mayıs Üniversitesi Yayınları.

Yakartepe, E. Ç. ve Binan, C. (2011). İstanbul'un Modernleşme Dönemi Otelleri (1840-1914), Megaron, 6(2): 79-94.
Yılmaz, Ö. D. (2007). Dünyada ve Türkiye'de Turizmin Tarihsel Gelişimi. İçinde Orhan İçöz (Editör), Genel Turizm Turizmde Temel Kavramlar ve Illkeler, (ss. 21-37). Ankara: Turhan Kitabevi.

Yüksel, A. (2010). Zamansız Bir Teşebbüs: I. Dünya Savaş1 Yıllarında Osmanlı İmparatorluğu'nda Turizmi Geliştirme Gayretleri. Doğu Batı, 52 (Osmanlılar II): 201-225.

Yüksel, A. (2012). II. Abdülhamid Döneminde Bilimsel, Kültürel ve Turistik Amaçlarla Osmanlı Ülkesine Gelen Almanlar, Jasss, 5 (5): 413-433.

\section{EKLER}

Ek1. Otel ve Misafirhane Sahiplerinin Tutacağ 1 Kayıt Defterlerinden Bir Örnek (Takvim-i Vekayi, No: 1081, 10 Mart 1328/23 Mart 1912, s. 2.)

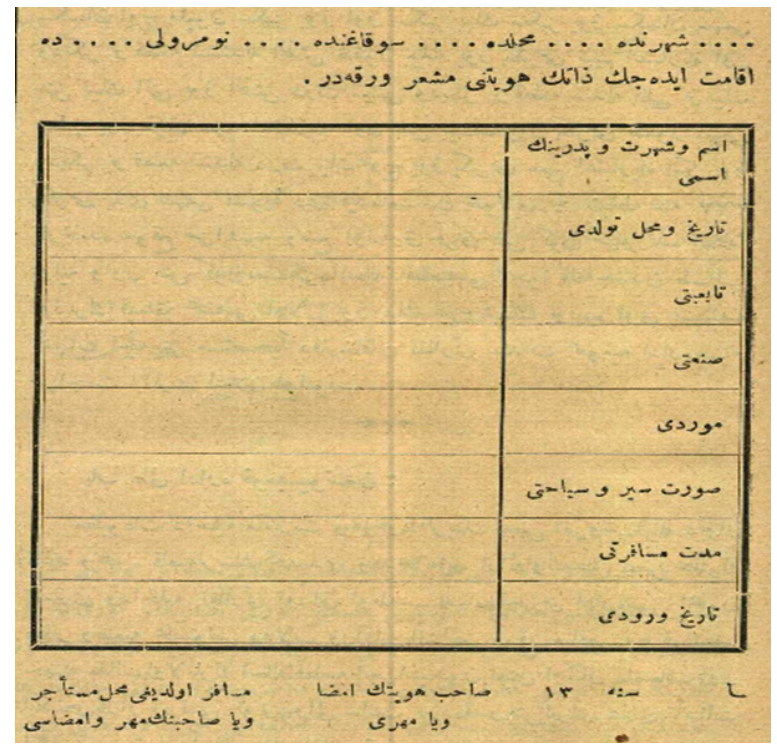

Ek 2. Ek-1'de Verilen Kayıt Defteri Örneğinin Sadeleştirilerek Günümüz Türkçesine Aktarılmış Tablosu

\begin{tabular}{|l|l|}
\hline \multicolumn{2}{|c|}{$\begin{array}{c}\text { şehrinde ... mahalde ... sokağında ... numaralı ... da } \\
\text { ikamet edecek zatın hüviyetini bildirir varakadır. }\end{array}$} \\
\hline İsim, şöhret ve babasının ismi & \\
\hline Doğum tarihi ve yeri & \\
\hline Tabiiyeti & \\
\hline Mesleği & \\
\hline Geliş tarihi & \\
\hline Seyahat şekli & \\
\hline Konaklayacağ1 süre & \\
\hline Dönüş tarihi & \\
\hline Tarih -Hüviyet sahibinin imza veya mührü- İşletme sahibi- \\
\multicolumn{2}{r}{ nin müh ve imzası } \\
\hline
\end{tabular}




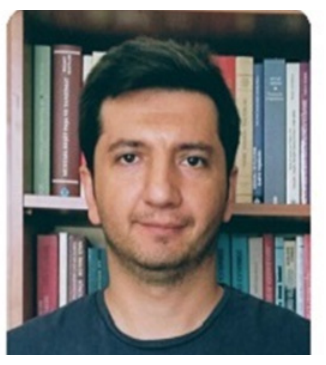

\section{Emrah ÇETIN}

Erciyes Üniversitesi Fen-Edebiyat Fakültesi Tarih Bölümü'nden 2007 yılında mezun oldu. Yüksek Lisans derecesini 2009 yılında Erciyes Üniversitesi Sosyal Bilimler Enstitüsü Yakınçağ Tarihi Anabilim Dalı'ndan, doktora derecesini de 2013 yılında Ankara Üniversitesi Sosyal Bilimler Enstitüsü Yakınçağ Tarihi Anabilim Dalı'ndan aldı. 2009 yılında Bartın Üniversitesi'nde çalışmaya başladı. Halen Bartın Üniversitesi Edebiyat Fakültesi Tarih Bölümü'nde görev yapmaktadır. Temel çalışma alanları, yakınçă̆ Osmanlı sosyo-ekonomik tarihi, kurumlar tarihi, ulaşım tarihi ve şehir tarihidir. 